\title{
Jacobsen syndrome: report of a patient with severe eye anomalies, growth hormone deficiency, and hypothyroidism associated with deletion $11(\mathrm{q} 23 \mathrm{q} 25)$ and review of 52 cases
}

\author{
E K Pivnick, G V N Velagaleti, R S Wilroy, M E Smith, S R Rose, R E Tipton, \\ A T Tharapel
}

Division of Clinical Genetics, Department of Pediatrics,

University of

Tennessee, 711

Jefferson Avenue,

Memphis, TN 38163, USA

E K Pivnick

G V N Velagaleti

R S Wilroy

M E Smith

A T Tharapel

Division of

Endocrinology,

Department of

Pediatrics, LeBonheur

Children's Medical

Center, University of

Tennessee, Memphis,

TN 38105, USA

$S$ R Rose

Intensive Care Unit, Baptist Hospital East, Memphis, TN 38120,

USA

R E Tipton

Correspondence to: Dr Pivnick.

Received 27 December 1995 to publication 24 April 1996

\begin{abstract}
We have evaluated a patient with Jacobsen syndrome. The patient presented with growth retardation, hypotonia, trigonocephaly, telecanthus, downward slanting palpebral fissures, bilateral inferior colobomas (of the iris, choroid, and retina), hydrocephalus, central nervous system (CNS) abnormalities, and an endocardial cushion defect, features commonly seen in Jacobsen syndrome. Endocrine evaluation showed growth hormone deficiency and central hypothyroidism. Chromosome analysis showed a 46,XX,del(11)(q23q25) de novo karyotype. Cytogenetically, the deletion appeared to include most of bands 11q23 and q24 and a portion of q25. Using chromosome specific paint probe, a combination of chromosome 11 centromere, telomere, and region specific cosmid probes from 11q14.1-14.3, 11q23.3, and $11 \mathrm{q} 24.1$, we have localised the deletion breakpoint to q24.1. Phenotype-karyotype correlation of patients with Jacobsen syndrome and specific deletions of chromosome 11q has enabled us to suggest that the critical region for this syndrome lies in close proximity to cytogenetic band 11q24. Although growth retardation is a consistent finding in $11 \mathrm{q}$ deletion syndrome, the presence of hypothalamic-pituitary hormone deficiency has not been reported previously.
\end{abstract}

(F Med Genet 1996;33:772-778)

Key words: Jacobsen syndrome; deletion 11(q23q25).

Jacobsen syndrome, also known as $11 \mathrm{q}-$ syndrome, is a rare, clinically recognisable condition. The deletion in most cases involves bands distal to $11 \mathrm{q} 23 .{ }^{1}$ To date, 52 cases have been reported in which variable segments of $11 \mathrm{q}$ were deleted. Of the 52 reported cases with Jacobsen syndrome, the majority are terminal deletions $(44 / 52=84.6 \%)$ while the remaining were reported to be interstitial deletions. Most of these cases (45 of 52) result from de novo deletions. The remaining cases are the result of familial balanced translocations $\mathrm{s}^{1-3}$ and ring chromosomes. ${ }^{4-6}$ Fryns et al ${ }^{2}$ suggested that the deletion of sub- band $11 \mathrm{q} 24.1$ is crucial for the full clinical expression of the syndrome.

The published cases have shown a broad spectrum of phenotypic variability. The most consistent phenotypic findings are psychomotor and growth retardation, trigonocephaly, and facial dysmorphism including telecanthus, downward slanting palpebral fissures, and a "carp shaped" mouth. Also reported are ocular anomalies, such as ptosis, strabismus, cataracts, glaucoma, and colobomas. Congenital heart defects occur in half of the patients. ${ }^{7}$ In this report, we describe a patient with an apparent de novo interstitial del(11)(q23q25) and severe eye anomalies, hydrocephalus, white and grey matter CNS abnormalities, growth hormone deficiency, and central hypothyroidism, and review the previously published cases of Jacobsen syndrome involving deletion of the long arm of chromosome 11 .

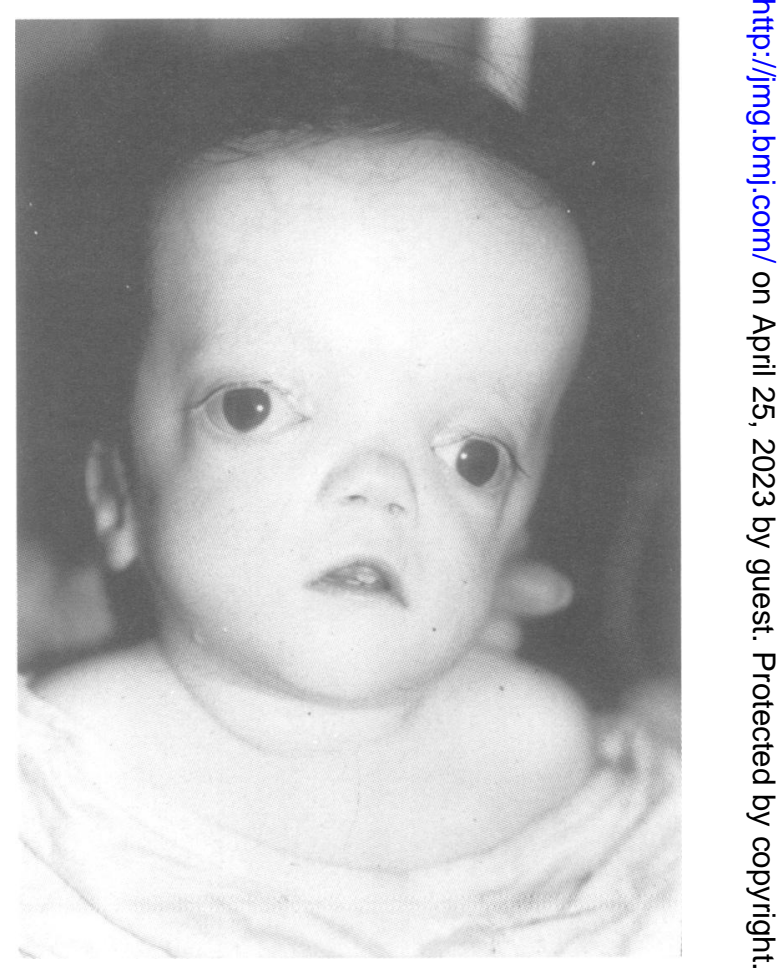

Figure 1 The proband aged 11 months. Note ocular hypertelorism, telecanthus, downward slanting palpebral fissures, colobomas, and short nose. 


\section{Case report}

The proband was the product of the second pregnancy of non-consanguineous parents. Both parents were 26 years of age at the time of conception. The pregnancy was uneventful and delivery was at term. At birth, the proband weighed $2165 \mathrm{~g}$ ( $<5$ th centile) and the head circumference was $33 \mathrm{~cm}$ (10th centile). Apgar scores were 7 at one minute and 8 at five minutes. Physical features noted at birth were hypotonia, trigonocephaly with bulging forehead, shallow orbits, hypertelorism, downward slanting palpebral fissures, and bilateral inferior colobomas of the irides which extended to the choroid and retina. The upper eyelashes were abundant while the lower eyelashes were sparse. The ears were poorly formed and low set. The eyelids could not be completely closed owing to facial diplegia. Brain stem auditory evoked response indicated moderate bilateral hearing loss. Echocardiogram disclosed an endocardial cushion defect. Ultrasonography of the head showed mild symmetrical ventriculomegaly.

The proband was re-evaluated at 11 months of age. She was severely developmentally
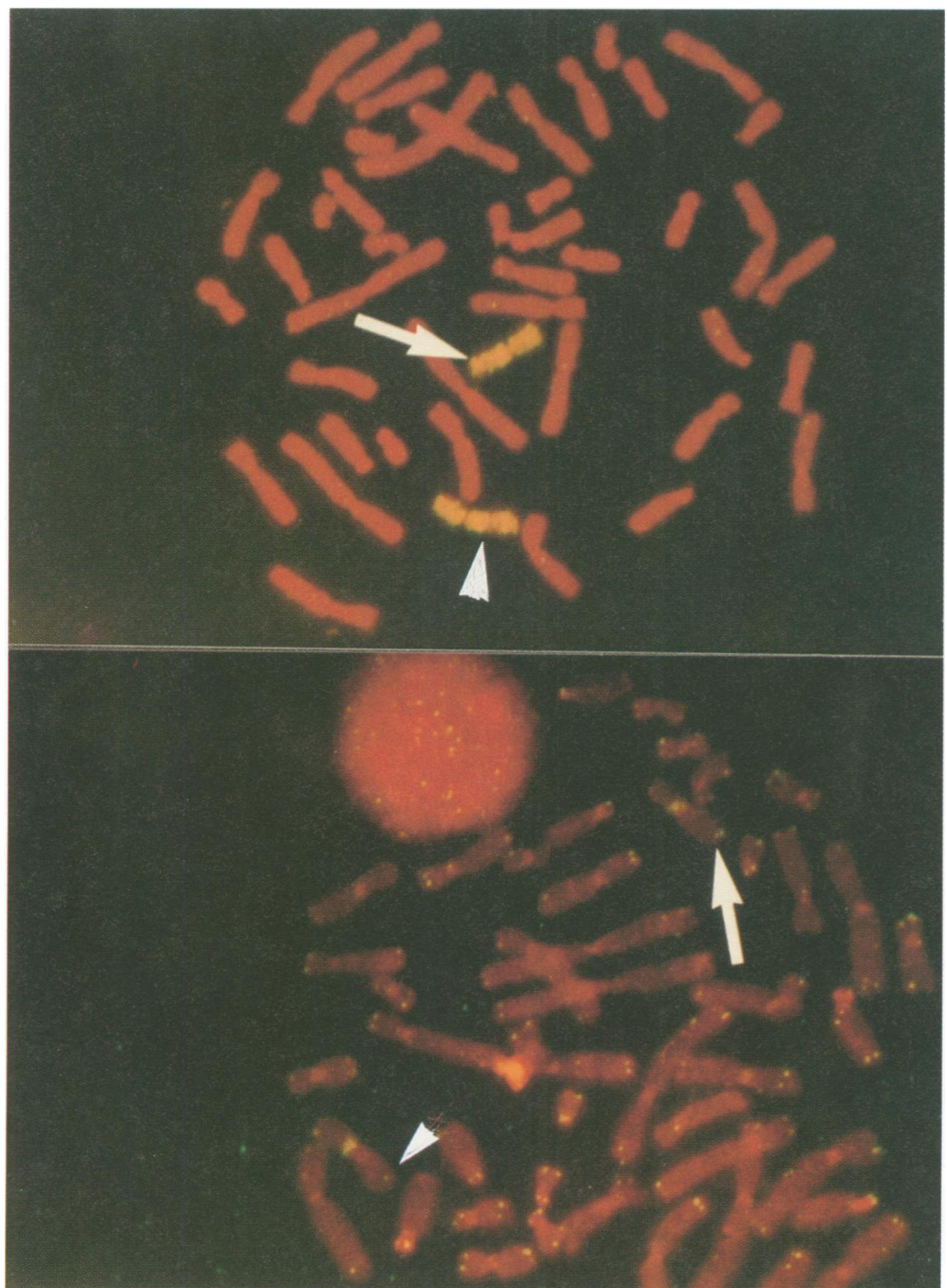

Figure 3 (Top) FISH with chromosome 11 specific paint probe. The deleted chromosome is marked by an arrow and the normal homologue by an arrowhead. (Bottom) FISH with telomere cocktail probe for all human chromosomes and sequential FISH using alpha satellite for 11 and human telomere probe. Arrow denotes the deleted 11 with telomere on the deleted end. Arrowhead denotes the normal chromosome.

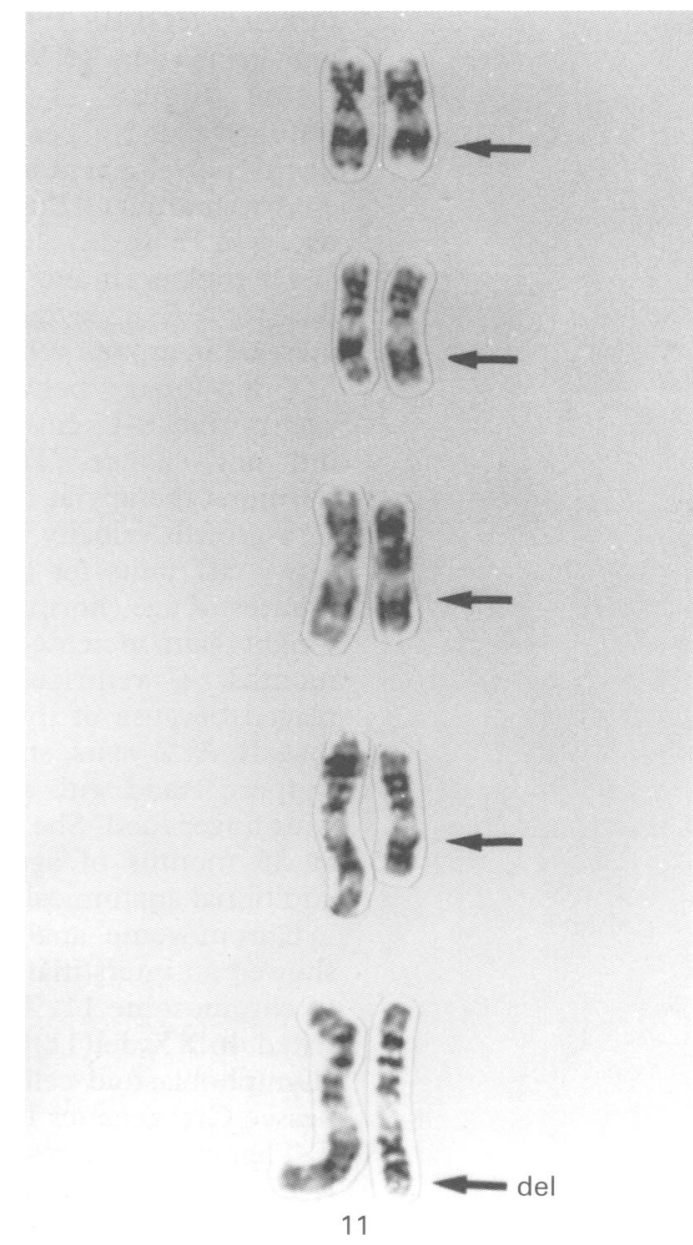

Figure 2 Partial karyotype of chromosomes 11 of the proband. Arrow shows the deleted chromosome.

delayed with marked growth retardation. A significant characteristic noted was the disproportionately large head with bulging anterior fontanelle (fig 1). Facial dysmorphism remained unchanged. She was unable to make meaningful sounds or sit without support.

Computerised tomography (CT) scan of the head showed thickened, abnormal grey matter in addition to the deficiency of white matter and disproportionate progressive ventriculomegaly involving the lateral and third ventricles. Magnetic resonance imaging (MRI) showed a small infundibulum and pituitary gland. A neuronal migrational disorder with polymicrogyria or pachygyria was present in the cerebral hemispheres. Because of the severe short stature, an endocrine evaluation was undertaken.

Growth velocity was $4.1 \mathrm{~cm} /$ year, well below expected (normal 13-20 cm/year) for age. Her growth velocity was at $-9.1 \mathrm{SD}$ units for age. Weight gain was $1.2 \mathrm{~kg} /$ year (normal 4 $\mathrm{kg} /$ year). T4 was $4.3 \mu \mathrm{g} / \mathrm{dl}$ (normal 7-14), free T4 was $0.76 \mathrm{ng} / \mathrm{dl}$ (normal 0.9-1.85), thyroid stimulating hormone (TSH) was $1.9 \mu \mathrm{U} / \mathrm{ml}$ (normal $0.5-4.6$ ), reverse $\mathrm{T} 3$ was $18 \mathrm{ng} / \mathrm{dl}$ (normal 10-50). These values were consistent with central hypothyroidism. A TSH surge test confirmed the diagnosis with a nocturnal TSH rise of only $17 \%$ (normal $50-300 \%$ ). Growth hormone $(\mathrm{GH})$ screening tests produced low values with insulin-like growth factor binding 
protein 3 (IGFBP 3) $0.2 \mathrm{mg} / 1$ (normal 0.7-2.5) and insulin-like growth factor-I (IGF-I) $<10$ $\mathrm{mg} / \mathrm{ml}$ (normal 11-206). Arginine-L-DOPA testing yielded a peak stimulated $\mathrm{GH}$ of 9.2 $\mathrm{ng} / \mathrm{ml}$ (polyclonal radioimmunoassay), consistent with partial GH deficiency. A morning cortisol was $15 \mu \mathrm{g} / \mathrm{dl}$.

Thyroid hormone therapy was begun at a dose of $8.3 \mu \mathrm{g} / \mathrm{kg} /$ day which resulted in an increase in growth velocity to $9.8 \mathrm{~cm} /$ year $(-2.8$ SD units for age) between 16 and 22 months of age (normal $8-15 \mathrm{~cm} /$ year). Rate of weight gain did not change. The addition of growth hormone therapy at the age of 22 months led to a growth velocity increase to $10.6 \mathrm{~cm} /$ year (+0.2 SD units for age) between 22 and 26 months of age (normal 6-12 cm/year). Rate of weight gain increased to $3.2 \mathrm{~kg} /$ year. At 18 months, a ventriculoperitoneal shunt was placed because of the progressive ventriculomegaly. At 2 years, she was able to sit without support, stand with support, and feed herself with finger food. She died of septic meningitis at 26 months of age. Necropsy showed no additional anatomical abnormalities.

Chromosome analysis of the lymphocytes showed an interstitial deletion of the long arm of chromosome 11. The karyotype was designated 46,XX,del(11)(q23q25) de novo (fig 2). (Lymphoblastoid cell line, University of Tennessee Cytogenetics Laboratory No 93-471, A $\mathrm{T}$ Tharapel.) Fluorescent in situ hybridisation (FISH) with chromosome 11 specific paint probe did not show evidence of a cryptic translocation (fig 3, top). Region specific cosmid probes cSRL1h6, c11q4b7, and cSRL1c8, hybridising to $11 \mathrm{q} 14.1-\mathrm{q} 14.3,11 \mathrm{q} 23.3$, and $11 \mathrm{q} 24.1$, respectively (probes courtesy of Dr G Evans) showed that the deletion extended from a region distal to band q24.1 (fig 4A-C). Sequential FISH analysis with chromosome 11 specific centromere probe and telomere probe showed the presence of a telomere on the deleted chromosome 11 (fig 3, bottom). These results, in conjunction with the $G$ banded nature of the deleted chromosome, prompted us to interpret the karyotype as an interstitial deletion. However, the possibility of a terminal deletion at $11 \mathrm{q} 24.1$ with regeneration of the telomere ${ }^{8}$ cannot be excluded with certainty.

\section{Discussion}

Review of published reports showed that the severity of the observed clinical abnormalities in patients with Jacobsen syndrome are not clearly correlated with the extent of the deletion. Thus, there is no clear phenotypekaryotype correlation in patients with Jacobsen syndrome. The phenotype-karyotype relationship in the present case and of previously reported cases is summarised in tables 1,2 , and $3 .^{1-7} 9-43$

Our search identified 52 patients with Jacobsen syndrome of which 47 were the result of de novo $11 \mathrm{q}$ deletions. In 28 of the 47 patients, the deletion extended from band 11q23 to qter, while interstitial deletions occurred in eight of the 52 cases. $^{38-40}{ }^{42}{ }^{44-46}$ However, no clear distinction can be made between the

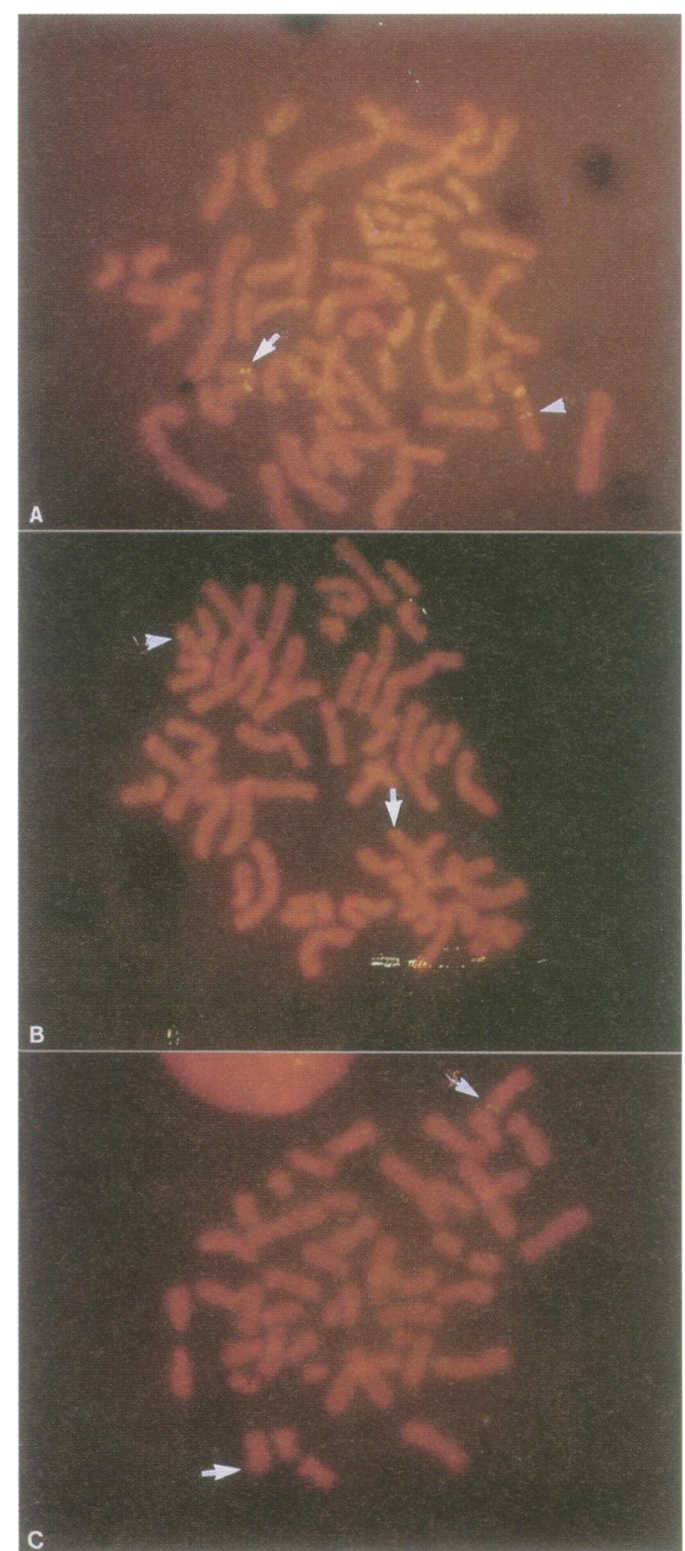

Figure 4 FISH with region specific cosmid probes from the long arm of chromosome 11. (A) Simultaneous FISH with cosmid cSRL1h6 localised to 11q14.1-q14.3 and alpha satellite for chromosome 11. Both homologues of chromosome 11 show the signals indicating that the deletion is distal to 11q14.3. The deleted chromosome is marked by an arrow and the normal homologue is by arrowhead. (B) Cosmid c11q4b7 localised to 11q23.3. Both homologues of chromosome 11 show the signals indicating that the deletion is distal to 11q23.3. Note the location of the signal on the deleted chromosome in comparison to the normal homologue. The deleted chromosome is marked by an arrow and the normal homologue by an arrowhead. (C) Cosmid cSRL1c8 localised to 11q24.1. Only the normal

chromosome 11 shows the signals. Absence of signals on the deleted chromosome indicates the breakpoint is at 11q24.1.

The deleted chromosome is marked by an arrow and the normal homologue by an arrowhead.

interstitial versus terminal deletions in relation to clinical manifestations, except for a causal relationship between the degree of psychomotor impairment and extent of deletion in a few patients. ${ }^{47}$ Attempts to correlate other major clinical manifestations with karyotype were unsuccessful.

It has been suggested that the presence of the $11 \mathrm{q}$ - phenotype depended on the loss of genetic material between band $11 \mathrm{q} 24.1$ and the terminal end of the long arm of chromo- 
Table 1 Reveiw of phenotype-karyotype correlations involving terminal deletions of the long arm of chromosome 11

\begin{tabular}{|c|c|c|c|c|c|c|c|c|}
\hline \multirow[b]{3}{*}{ Findings } & \multicolumn{6}{|c|}{ Terminal deletions } & \multicolumn{2}{|l|}{ Ring } \\
\hline & \multirow{2}{*}{$\begin{array}{l}q 21 \\
(n=3)\end{array}$} & \multirow{2}{*}{$\begin{array}{l}q 22 \\
(n=2)\end{array}$} & \multicolumn{2}{|l|}{$q 23$} & \multicolumn{2}{|l|}{$q 24$} & \multirow{2}{*}{$\begin{array}{l}q 15-q 25 \\
(n=2)\end{array}$} & \multirow{2}{*}{$\begin{array}{c}q 24-q t e r \\
(n=1)\end{array}$} \\
\hline & & & De novo $(n=25)$ & $\begin{array}{l}\text { pat } \\
t(11 ; 21) \\
(n=2)\end{array}$ & $\begin{array}{l}\text { De novo } \\
(n=7)\end{array}$ & $\begin{array}{l}t(8 ; 11) \\
\text { pat } t(11 ; 14) \\
(n=2)\end{array}$ & & \\
\hline Male & 1 (mosaic) & 1 & $\begin{array}{l}8(2 \text { low gr } \\
\text { mosaic) }\end{array}$ & - & 3 & 2 & - & - \\
\hline Female & 2 & 1 & 17 & 2 & 4 & - & 2 & 1 \\
\hline Prenatal growth retardation & $1 / 3$ & $1 / 2$ & $5 / 25$ & 2 & $5 / 7$ & - & $1 / 2$ & - \\
\hline Short stature & $1(2=\mathrm{ID})$ & - & $12 / 25$ & 2 & $6 / 7$ & - & $2 / 2$ & - \\
\hline $\begin{array}{l}\text { Psychomotor retardation } \\
\text { Psom }\end{array}$ & $1 / 1 \mathrm{ID}$ & $1 / 2$ & $12 / 25$ & 2 & $5 / 7$ & 2 & - & + \\
\hline Trigonocephaly & $1 / 3$ & $2 / 2$ & $18 / 25$ & 2 & $3 / 7$ & $1 / 2$ & - & + \\
\hline $\begin{array}{l}\text { Ventriculomegaly-hydocephalus or anatomical } \\
\text { abnormality }\end{array}$ & $1 / 3$ & NA & $3 / 25$ & NA & $\mathrm{NA}$ & - & - & NA \\
\hline CNS white grey matter abnormality & - & NA & $1 / 25$ & NA & $1 / 7$ & NA & $1 / 2$ & NA \\
\hline $\begin{array}{l}\text { Abnormal face; hypertelorism, "carp shaped" } \\
\text { mouth; flat nasal bridge; abnormal, low set ears }\end{array}$ & $1 / 3$ & $2 / 2$ & $24 / 25$ & 2 & $3-3 \mathrm{ID} / 7$ & $1 / 2$ & - & + \\
\hline $\begin{array}{l}\text { Congenital heart defect } \\
\text { Collo }\end{array}$ & $1 / 3$ & $2 / 2$ & $12 / 25$ & 2 & $3 / 7$ & _- & $1 / 2$ & + \\
\hline Eye abnormality including ptosis & $1 / 3$ & $2 / 2$ & $16 / 25$ & $1 / 2$ & 5/7 (ptosis) & NA & $1 / 2$ & - \\
\hline Documented endocrine abnormality & NA & NA & NA & NA & NA & - & & NA \\
\hline Thrombocytopenia or pancytopenia & - & - & $4 / 25$ & - & $1 / 7$ & - & $\begin{array}{l}-(1 / 2 \\
\text { pancytopenia }\end{array}$ & - \\
\hline Neonatal death (stillborn) & $\begin{array}{l}2 / 3 \\
\text { stillborn }\end{array}$ & - & $6 / 25$ & $1 / 2$ & - & - & - & - \\
\hline Died before second year & - & - & _- & $1 / 2$ & - & _ & - & + \\
\hline Reference numbers & $9-11$ & 12,13 & $2,7,14-32$ & 1 & $33-37$ & 2,3 & 5,6 & 4 \\
\hline
\end{tabular}

NA $=$ not analysed.

ID $=$ insufficient data.

$+=$ present.

- = absent.

Table 2 Review of phenotype-karyotype correlations involving interstitial deletion of the long arm of chromosome 11

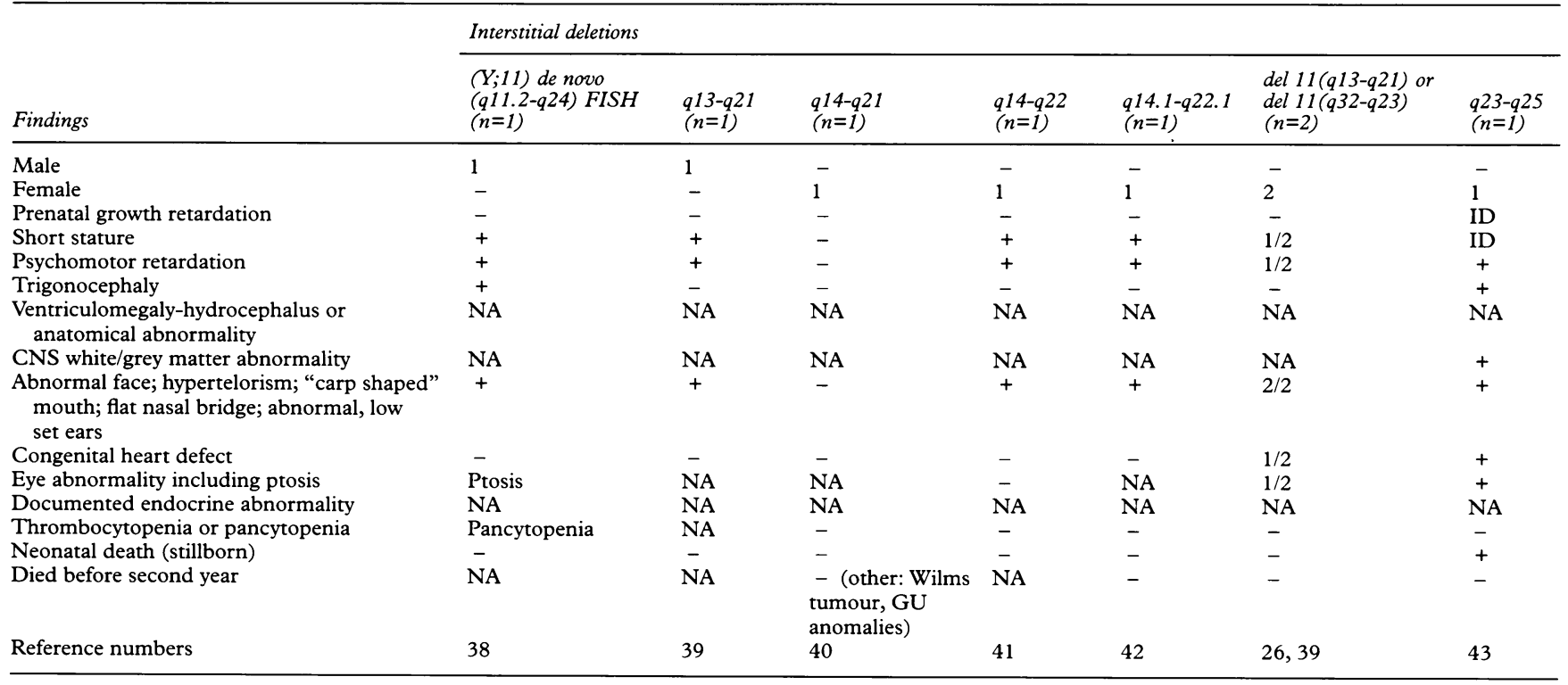

NA $=$ not analysed.

ID = insufficient data.

$+=$ present .

- = absent.

some $11,{ }^{35}$ while others suggested that subband $11 \mathrm{q} 24.1$ is the critical region for the expression of Jacobsen syndrome. ${ }^{2}$ However, cases with interstitial deletions proximal to the suggested critical region have been reported with some features of Jacobsen syndrome. ${ }^{42}$ One of the previously published cases had identical breakpoints (11q23q25) to those seen in our patient. ${ }^{43}$ Although both our patient and the patient of Sirota et $a l^{43}$ had trigonocephaly, facial dysmorphism, and endocardial cushion defect, the latter had complex genitourinary malformations and died at 23 days of age. Endocrine and ophthalmological abnormalities were not assessed. Our FISH studies with region specific cosmid probes and review of all the true deletion cases with Jacobsen syndrome enabled us to delineate the smallest region of overlap to include band $11 \mathrm{q} 24$ (fig 5), with trigonocephaly, abnormal facies, eye anomalies, and congenital heart disease as the most commonly seen features. On the distal portion of $11 \mathrm{q}$, no candidate gene has yet been identified for Jacobsen syndrome. However, the neu- 
Table 3 Summary of phenotype-karyotype correlations of the 51 previously published cases and the present case. All results given as No (\%)

\begin{tabular}{|c|c|c|c|}
\hline \multirow[b]{2}{*}{ Findings } & \multicolumn{2}{|l|}{ Previous cases } & \multirow{2}{*}{$\frac{\text { Present case }(\mathrm{VH})}{q 23.3-q 25(n=1)}$} \\
\hline & Terminal deletion $(n=44)$ & Interstitial deletion $(n=8)$ & \\
\hline Male & $14(30)$ & $2(25)$ & 0 \\
\hline Female & $30(70)$ & $6(75)$ & 1 \\
\hline Prenatal growth retardation & $15(35)$ & - & + \\
\hline Short stature & $23(51)$ & $5(60)$ & + \\
\hline Psychomotor retardation & $24(53)$ & $6(75)$ & + \\
\hline Trigonocephaly & $28(65)$ & $2(25)$ & + \\
\hline Ventriculomegaly-hydrocephalus or anatomical abnormality & $4(9)$ & - & + \\
\hline CNS white/grey matter abnormality & $3(7)$ & $1(13)$ & + \\
\hline $\begin{array}{l}\text { Abnormal face; hypertelorism, "carp shaped" mouth; flat nasal bridge; } \\
\text { abnormal, low set ears }\end{array}$ & $35(80)$ & $7(90)$ & + \\
\hline Congenital heart defect & $22(50)$ & $2(25)$ & + \\
\hline Eye abnormality including ptosis & $26(60)$ & $3(38)$ & + \\
\hline Documented endocrine abnormality & $1(2)$ & - & + \\
\hline Thrombocytopenia or pancytopenia & $6(13)$ & $1(13)$ & - \\
\hline Neonatal death (stillborn) & $9(20)$ & $1(13)$ & - \\
\hline Died before second year & $2(5)$ & - & - \\
\hline
\end{tabular}

ral cell adhesion molecule (NCAM) that is localised to $11 \mathrm{q} 23$ might play a role in eye development and myelin formation. ${ }^{48}$

Many possible explanations have been suggested for the apparent lack of phenotypekaryotype correlation in Jacobsen syndrome patients. These explanations range from undetected mosaicism to redundant gene loci.

In five of the 52 cases, chromosome mosaicism was observed in peripheral blood.

Table 4 Eye anomalies in partial monosomy $11 q$

\begin{tabular}{lcl}
\hline & Present case & $\begin{array}{l}\text { Previously } \\
\text { reported cases } \\
(29 / 52)\end{array}$ \\
\hline Eefect & + & $19 / 29$ \\
Eyelid ptosis & + & $1 / 29$ \\
Iris coloboma & + & $7 / 29$ \\
Chorioretinal coloboma & + & $1 / 29$ \\
Cyclopia & - & $1 / 29$ \\
Peter's anomaly & - & $1 / 29$ \\
Glaucoma & - & $1 / 29$ \\
Cataract & - & $1 / 29$ \\
Strabismus & + & $4 / 29$ \\
\hline
\end{tabular}

Extent of various deletions

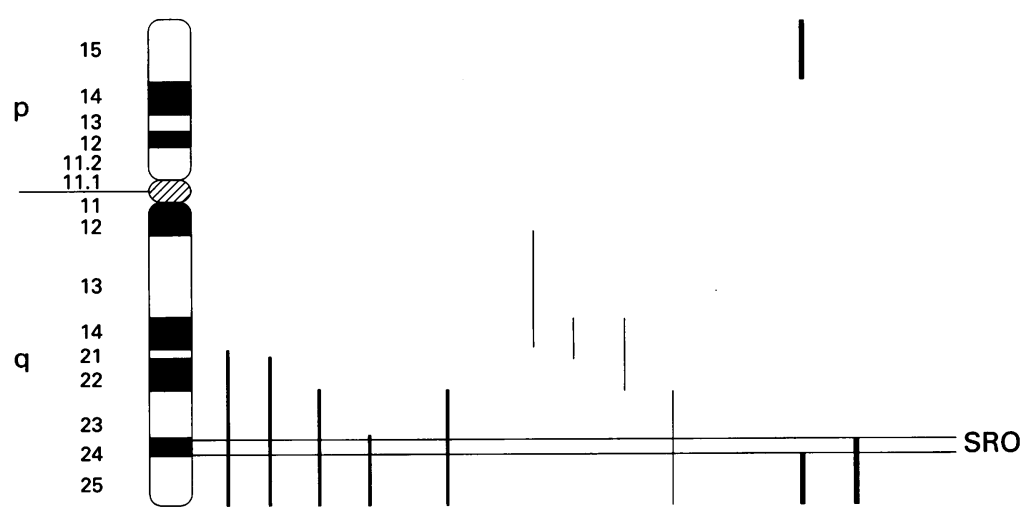

$(3)(2)(28)(9) \quad(V H) \quad(1)(2)(2)(1)$

(2) (1)

$\begin{array}{|ll|}\text { - Interstitial deletion } & \text { SRO = smallest region of overlap } \\ \text { - Terminal deletion } & \mathrm{VH}=\text { present case } \\ \text { - Ring chromosome } & \end{array}$

Figure 5 Schematic representation of various deletions reported in Facobsen syndrome and the delineation of minimal overlapping region common to all these deletions. The numbers in parentheses under the vertical bars indicate the number of cases. VH represents the present case.
Two of these patients displayed a very low percentage of normal cells. ${ }^{3146}$ Two other patients had low grade mosaicism attributed to the unstable ring chromosome. ${ }^{56}$ One stillborn male infant had $50 \%$ normal cells in addition to the $11 \mathrm{q}$ - cell line. ${ }^{9}$ It was suggested that the deficient part of $11 \mathrm{q}$ might contain redundant gene loci. ${ }^{10}$ Based upon the "gene dosage compensation" theory of Ohno, ${ }^{49}$ it was suggested that genes on the deficient part of the chromosome are compensated by homologous DNA sequences on apparently non-homologous chromosomes. It was also assumed that the degree of abnormalities of partial monosomy $11 \mathrm{q}$ is significantly influenced by the overall genetic makeup of the person. ${ }^{43}$ Some of the cases of partial monosomy $11 \mathrm{q}$ have mild phenotypic abnormalities. This was not expected on the basis of phenotype-karyotype relationships known from other chromosome deletion syndromes. ${ }^{10}$ The published cases show a wide range of phenotypic variability which could be related either to differences in the size of the deleted region at the molecular level, the different ages of the patients (stillborn to 21 years), or a non-homogeneous criterion of classification. $^{7}$

CT scans in eight of 51 reported cases showed abnormal CNS white matter in four and ventriculomegaly in the remaining four. Ocular findings in our patient were unusually complex compared to previously reported cases (table 4). Most of the patients with $11 \mathrm{q}$ deletion syndrome had short stature, but none of them had documented growth hormone deficiency, or central or primary hypothyroidism. ${ }^{50}$ However, Valente et at described a girl with ring 11 chromosome who had primary hypothyroidism but no growth hormone deficiency. The hypothalamic pituitary hormone deficiencies in our patient may be secondary to the presentation of progressive ventriculomegaly/hydrocephalus, may result from abnormalities of hypothalamic grey matter, or may be an undetected finding in other children with Jacobsen syndrome. Developmental progress in our patient improved with hormone therapy, perhaps only related to the passage of time, but possibly also related to improved muscle tone resulting from hormone therapy. 
It is interesting that a folate sensitive fragile site FRA11B has been localised to $11 \mathrm{q} 23.3,{ }^{51}$ which is also the critical region for Jacobsen syndrome..$^{30} 4752$ Voullaire et $a l^{30}$ reported a case in which the proband's mother and brother showed folate sensitive fragility at $11 \mathrm{q} 23$.3. It has been reported that fragile sites may cause chromosome breakage in vivo ${ }^{53}$ and evidence has been accumulated that over half of the breakpoints during human chromosome evolution have occurred at close proximity to fragile sites, ${ }^{55}$ thus implicating fragile sites in chromosome breakage. Recent studies have documented that breakage at FRA11B might be a factor contributing to $11 \mathrm{q}$ terminal deletions. ${ }^{4756}$ Most of the folate fragile sites are shown to be associated with trinucleotide repeat expansions and changes in regional methylation. ${ }^{57.59}$ Numerous human genes have been identified with trinucleotide repeats located at the $5^{\prime}$ untranslated regions. ${ }^{60}$ One such human gene is CBL2, a proto-oncogene, which is also localised to chromosome 11q23.3. Recent reports have localised FRA11B to the trinucleotide repeat of CBL2 proto-oncogene and have shown an association with $11 \mathrm{q}$ deletion typically seen in Jacobsen syndrome..$^{52}$ Interestingly, band $11 \mathrm{q} 23$ has also been shown to be involved in structural rearrangements in acute monocytic leukaemia and acute lymphoblastic leukaemia rearrangements. ${ }^{61}$ There has been documented evidence that chromosome rearrangements or deletions are key secondary events leading to tumour progression. Even though the CBL2 protooncogene with its trinucleotide repeat is not implicated in either of these malignancies, it is possible that FRA11B, colocalised to CBL2 trinucleotide repeat, might increase the incidence of chromosome deletions, thus indirectly influencing the tumour progression.

There has been an apparent abnormal sex ratio deviating towards females in patients with Jacobsen syndrome. Approximately $70 \%$ of the patients with $11 \mathrm{q}$ deletion were female (37/52), including the present case. In order to explain the preponderance of female patients with Jacobsen syndrome, it is hypothesised that the expression of $11 \mathrm{q}$ terminal deletion is somehow determined by the sex chromosome complement and that it contributes to a differential survival depending on the sex of the patient. ${ }^{16}$

In the majority of reported cases with Jacobsen syndrome, phenotype-karyotype correlations were not successful because of the limited precision in identification of the breakpoints and because of lack of marker studies. Molecular delineation of these deletions may ultimately aid in clarification of the phenotypekaryotype correlations.

The authors are grateful to the parents of the proband for their cooperation, to Kimberly Edwards for excellent technical help in preparation of chromosomes and banding, Ron Michaelis for cosmid preparation, and Kathy McCalla for secretarial help in preparing the manuscript.

1 Jacobsen P, Hauge M, Henningen K. An $(11 ; 21)$ translocation in four generations with chromosome 11 abnormalities in the offspring. Hum Hered 1973;23:368-85.
2 Fryns JP, Kleczkowska A, Buttiens M. Distal 11q monosomy. The typical $11 \mathrm{q}$ monosomy syndrome is due to deletion of subband 11q24.1. Clin Genet 1986;30:255-60.

3 Coco R, Penchaszadeh VB. Partial deficiency of long arm of chromosome No 11. F Genet Hum 1977;25:43-6.

4 Cousineau AJ, Higgins JV, Scott-Emaukpor AB. Brief clinical report. Ring 11 chromosome: phenotype-karyotype correlation with deletion of 11q. Am $\mathcal{J}$ Med Genet 1983;14:29-35.

5 Valente M, Muller H, Sparkes RS. Ring 11 chromosome (46,XX,r11(p15q25)). Hum Genet 1977;36:345-50.

6 Niikawa N, Jinno Y, Tomiyasu T, et al. Ring chromosome 11 $[46, \mathrm{XX}, \mathrm{r}(11)(\mathrm{p} 15 \mathrm{q} 25)]$ associated with clinical features of the 11q- syndrome. Ann Genet (Paris) 1981;3:172-5.

7 Obregon MG, Mingarelli R, Digilio M. Deletion 11q23-qter (Jacobsen syndrome). Report of three new patients. Ann Genet (Paris) 1992;35:208-12.

8 Meltzer PS, Guan XY, Trent JM. Telomere capture stabilizes chromosome breakage. Nature Genet 1993 4:252-5.

9 Helmuth RA, Weaver DD, Wills ER. Holoprosencephaly, ear abnormalities, congenital heart defect, and microphallus in a patient with $11 \mathrm{q}-$ mosaicism. Am $\mathrm{F}$ Med Genet 1989;32:178-81.

10 Faust J, Vogel W, Loning B. A case with 46,XX, del(11)(q21). Clin Genet 1974;6:90-7.

11 Hertz JM, Tommerup N, Sorensen FB, Henriques UV, Nielsen A, Therkelsen AJ. Partial deletion 11 q: report of a case with a large terminal deletion 11q21-qter without loss case with a large terminal deletion 11q21-qter without loss
of telomeric sequences, and review of the literature. Clin of telomeric sequences,
Genet 1995;47:231-5.

12 Linarelli GP, Pai KG, Pan SF, Rubin HM. Anomalies associated with partial deletion of long arm of chromosome 11 $\mathcal{f}$ Pediatr 1975;86:750-2.

13 Felding I, Mitelman F. Case report. Deletion of the long arm of chromosome 11: a clinical entity. Acta Paediatr Scand 1979;68:635-8.

14 Wardinsky TD, Weinberger E, Pagon RA, Clarren SK, Thuline HC. Partial deletion of the long arm of chromosome 11 [del(11)(q23.3 qter)] with abnormal white matter. Am 7 Med Genet 1990;35:60-3.

15 Hausmann C, Back E, Wolff G, Voiculescu I. Deletion $11 \mathrm{q} 23.3$ without familial predisposition. Hum Genet 1988;

16 Frank J, Riccardi VM. The 11q- syndrome. Hum Genet 1977;35:241-6.

17 Larson SA, Yeatman GW, Riccardi VM. Deletion of $11 \mathrm{q}$ report of two cases and a review: In: Bergsma D, ed. Cytogenetics, environment, and malformation syndromes. New York: Alan R Liss, for the National Foundation-March of Dimes. Birth Defects 1976;XII(5):125-30.

18 Engel E, Hirschberg CS, Cassidy SB, McGree BJ. Chromosome 11 long arm partial deletion: a new syndrome. $A m \mathcal{F}$ Ment Defic 1976;80:473-5.

19 Bresson JL Noir A. Monosomie partielle 11q. Une nouvellle observation. Ann Genet (Paris) 1977;20:63-6.

20 Cassidy SB, Heller RM, Kilroy AW, McKelvey W, Engel E. Trigonocephaly and $11 \mathrm{q}$ phenotype. Ann Genet (Paris) 1977;20:67-9.

21 Kaffe S, Hsu LYF, Schdev RK, Phillips J, Hirschhorn K. Partial deletion of long arm of chromosome 11: $\operatorname{del}(11)(\mathrm{q} 23)$. Clin Genet 1977;12:323-8.

22 Mulcahy MT, Jenkyn J. The $11 \mathrm{q}-$ syndrome: another case report. Hum Genet 1977;36:239-42.

23 Leonard C, Courpotin C, Labrune B, Lepercq G, Kachaner J, Caut P. Monosomie partielle par deletion du bras long du chromosome 11: del(11)(q23). Ann Genet (Paris) 1979;22:1 15-20.

24 Lippe BM, Sparkes RS, Fass B, Neidengard L. Craniosynostosis and syndactyly: expanding the $11 \mathrm{q}-$ chromosomal deletion phenotype. F Med Genet 1980;17:480-2.

25 Lee ML, Sciorro LJ. Partial monosomy of the long arm of chromosome 11 in a severely affected child. Ann Gene (Paris) $1981 ; 24: 51-3$

26 McPherson E, Meissner L. 11q- syndrome: review and report of 2 cases. In: Nyhan WL, Jones KL, eds. Program and abstracts of March of Dimes 14th Annual Birth Defect Conference. New York: Alan R Liss, for the National Foundation-March of Dimes. Birth Defects 1982; XVIII (3B): 295-300.

27 Zabel B, Hansen S, Hilling U, Groting-Imhof H. A girl with partial long-arm deletion of chromosome 11 and familial pericentric inversion of chromosome 9. Hum Genet 1977; pericentric

28 Hyder DM, Bottomley SS, Bottomley RH. A new chromosome abnormality in idiopathic sideroblastic anemia 46,XY,del(11)(q23). Am ₹ Hematol 1978;55:239-45.

29 Schinzel A, Auf der Maur P, Moser H. Partial deletion of long arm chromosome 11 (del)(11)(q23): Jacobsen syndrome. $\mathcal{F}$ Med Genet 1977;14:438-44.

30 Voullaire LE, Webb GC, Leversha MA. Chromosome deletion at $11 \mathrm{q} 23$ in an abnormal child from a family with inherited fragility at $11 \mathrm{q} 23$. Hum Genet 1987;76:202-4.

31 Küstner W, Gebauer HJ, Majewski F. Report of a deletion 11 (qter-q23.3) and short review of the literature. Eur $\mathcal{F}$ Pediatr 1985;144:286-8.

32 Monteleone PL, Chen SC, Nouri-Moghaddam S, Blair JD, Tietjens M. Brief clinical report. Deletion of the long arm of chromosome 11, [del(11)(q23)]. Am f Med Genet 1982; 13:299-304.

33 Laurent C, Biemont MCI, Veyron M, Guilhot J, Guyilbaud P. Deux nouveaux cas de monosomie $11 \mathrm{q}$ partielle avec point de cassure en 11q24. Ann Genet (Paris) 1979;
22:239-41. 
34 Schwartz C, Mpofu C, Wraith JE. A terminal deletion of 11q. F Med Genet 1992;29:511-12.

35 O'Hare AE, Grace E, Edmunds AT. Deletion of the long arm of chromosome 11 [46,XX, del(11)(q24.1 qter)]. Clin Genet 1984;25:373-7.

36 Neavel CB, Soukup S. Deletion of (11)(q24.2) in a mother and daughter with similar phenotypes. Am $\mathcal{F}$ Med Gene 1994;53:321-4.

37 Feldman-Lewanda A, Morsey S, Reid CS, Wang-Jabs E. Two craniosynostotic patients with $11 \mathrm{q}$ deletions, and review of 48 cases. Am $\mathcal{f}$ Med Genet 1995;59:193-8.

38 Van Hemel JO, Eussen B, Wesby-van Swaay E, et al. Molecular detection of a translocation (Y;11) (q11.2;q24) in a 45,X male with signs of Jacobsen syndrome. Hum Genet 1992;88:661-7.

39 Klep-De Pater JN, De France HF, Bijlsma JB. Interstitial deletion of the long arm of chromosome 11 . f Med Genet 1985;22:224-6.

40 Stratton RF, Lazarus KH, Ritchie EJL, et al. Brief clinica report: deletion (11)(q14.1q21). Am $\mathcal{f}$ Med Genet 1994;49:294-8.

41 Bateman JB, Maumenee IH, Sparkes RS. Peter's anomaly associated with partial deletion of the long arm of chromosome 11. Am $\mathcal{F}$ Ophthalmol 1984;97:11-15.

42 Taillemite JL, Baheux-Morlier G, Roux CH. Deletion interstitielle du bras long d'un chromosome 11. Ann Genet (Paris) 1975;18:61-3.

43 Sirota L, Shabtai F, Landman I. New anomalies found in the 11q-syndrome. Clin Genet 1984;26:569-73.

44 Guc-Scekic M, Pilic-Radivojevic G, Mrdjenovic G, Djuric $\mathrm{M}$. Interstitial deletion of $11 \mathrm{q}$. 7 Med Genet 1989; 26:205-6.

45 Wakazono A, Masuno M, Yamaguchi S, et al. Interstitial deletion of the long arm of chromosome 11: report of a case and review of the literature. $f p n ~ f$ Hum Gene 1992;37:229-34

46 Carnevale A, Blanco B, Grether P, et al. Interstitial deletion of the long arm of chromosome 11. Ann Genet (Paris) 1987;30:56-8.

47 Penny LA, Dell'Aquila $M$, Jones $M$, et al. Clinical and molecular characterization of patients with distal 119 deletions. Am f Hum Genet 1995;56:676-83.
48 Ngynen $C$, Mattei $M$, Mattei J. Localization of the human NCAM gene to band q23 of chromosome 22. F Cell Biol 1986;102:711-15.

49 Ohno S. Evolution by gene duplication. Berlin: Springer, 1970.

50 Rose SR, Manasco PK, Pearce S, Nisula BC. Hypothyroidism and deficiency of the nocturnal thyrotropin surge in children with hypothalamic-pituitary disorders. 7 Clin Endocrinol Metab 1990;70:1750-5.

51 Sutherland GR, Jacky PB, Baker E, Manuel A. Heritable fragile sites on human chromosomes. $X$. New folatesensitive fragile sites: $6 \mathrm{p} 23,9 \mathrm{p} 21,9 \mathrm{q} 32,11 \mathrm{q} 23$. Am f Hum Genet 1983;35:432-7.

52 Jones C, Penny L, Mattina T, et al. Association of a chromosome deletion syndrome with a fragile site with the protooncogene CBL2. Nature 1995;376:145-9.

53 Glover T, Stein C. Induction of sister chromatid exchanges at common fragile sites. Am $\mathcal{F}$ Hum Genet 1987;41:822-30.

54 Glover T, Stein C. Chromosome breakage and recombination at fragile sites. Am F Hum Genet 1988;43:265-73.

55 Miro RA, Clemente I, Fuster C, Egozcue J. Fragile sites, chromosome evolution and human neoplasia. Hum Genet 1987;75:345-9.

56 Jones C, Slijepcevic P, Marsh S, et al. Physical linkage of the fragile site FRA11B and Jacobsen syndrome chromosome deletion breakpoint in 1qq23.3. Hum Mol Genet 1994; 3:2123-30.

57 Knight S, Flannery A, Hirst M, et al. Trinucleotide repeat amplification and hypermethylation of a $\mathrm{CpG}$ island in FRAXE mental retardation. Cell 1993;74:127-34.

58 Parrish JE, Oostra BA, Verkerk AJ, et al. Isolation of a GCC repeat showing expansion in FRAXF, a fragile site distal to FRAXA and FRAXE. Nature Genet 1994;8:229-35.

59 Nancarrow J, Kremer E, Holman $\mathrm{K}$, et al. Implications of FRA16A structure for the mechanism of chromosomal fragile sites genesis. Science 1994;264:1938-41.

60 Richards RI, Sutherland GR. Dynamic mutations: a new class of mutations causing human disease. Cell 1992; 70:709-12.

61 Kaneko Y, Maseki N, Takasaki N. Clinical and haematologic characteristic in acute leukemia with 11q23 translocations. Blood 1986;67:484-91. 